\title{
Postural hematürinin değerlendirilmesi: posterior nutcracker sendromu
}

\author{
Evaluation of postural hematuria: posterior nutcracker syndrome
}

Murat Yaşar Taş, Belda Dursun, Muhammet Arslan

Gönderilme tarihi:23.02.2021

Kabul tarihi:20.05.2021

Öz: Nutcracker sendromu sol renal venin abdominal aorta ile süperior mezenterik arter arasında ya da abdominal aorta ile vertebral kolon arasında sıkışmasından kaynaklanmaktadır. Sol renal venden inferior vena kavaya olan kan akımının dıştan bası nedeniyle azalması; artmış venöz basınç, böbrek konjesyonu, hematüri ve proteinüriye sebep olur. Ortostatik hematüri ile başvuran hastalarda akılda tutulmalıdır. Hematüriyle başvuran hastalarda öyküde hematürinin ortostatik yani ayakta kalmakla artıp artmadığının ve mesleğin sorgulanması son derece önemlidir. Dikkatli anemnez alınmaması sonucunda böbrek biyopsisini de içeren birçok gereksiz tetkik yapılması ve sonucunda net tanı konulamaması durumu hastalarda endişeye neden olabilir. Tanısal yöntemler doppler ultrasonografi, bilgisayarlı tomografi, MR ve altın standart yöntem olarak sol renal ven ile inferior vena cava arasındaki basınç farkının venografi ile ölçülmesidir. Nutcracker sendromunun yönetimi ise tartışmalıdır ve spontan remisyon nedeniyle özellikle genç ve hafif hematürisi olan kişilerde izlem tercih edilir. Ortostatik hematüri ile başvuran ve Posterior Nutcracker Sendromu tanısı alan genç bir kadın hasta vaka sunumu olarak tartışılmıştır.

Anahtar kelimeler: Hematüri, nutcracker sendromu, postural hematüri.

Taş MY, Dursun B, Arslan M. Postural hematürinin değerlendirilmesi: posterior nutcracker sendromu. Pam Tıp Derg 2021;14:930-932.

Abstract: Nutcracker sydrome is associated with extrinsic left renal vein compression between abdominal aorta and superior mesenteric vein or between abdominal aorta and vertebral column. Decreased blood flow from the left renal vein to the inferior vena cava due to external compression results in increased venous pressure, kidney congestion, hematuria and proteinuria. Patients with orthostatic hematuria should be screened for nutcracker syndrome. In patients presenting with hematuria, it is extremely important to question whether orthostatic hematuria increases with standing and the profession. As a result of not taking a careful anamnesis, many unnecessary tests, including kidney biopsy, and the inability to make a clear diagnosis as a result may cause anxiety in patients. Diagnostic methods are Doppler ultrasonography, computed tomography, MRI and, as the gold standard method, measuring the pressure difference between the left renal vein and the inferior vena cava by venography. The management of Nutcracker syndrome is controversial and because of spontaneous remission, follow-up is preferred especially in young people with mild hematuria. A young female patient who presented with ortostatic hematuria and diagnosed with posterior nutcracker syndrome is discussed hereby in the case report.

Key words: Hematuria, nutcracker syndrome, postural hematuria.

Tas MY, Dursun B, Arslan M. Evaluation of postural hematuria: posterior nutcracker syndrome. Pam Med J 2021;14:930-932.

\section{Giriş}

Nutcracker sendromu (NS), sol renal venin (SRV) abdominal aorta ile süperior mezenterik arter arasında (anterior nutcracker) ya da abdominal aorta ile vertebral kolon arasında (posterior nutcracker) sıkışmasından kaynaklanmaktadır [1-4]. Sol renal venden inferior vena kavaya olan kan akımının dıştan bası nedeniyle azalması; artmış venöz basınç, böbrek konjesyonu, hematüri ve proteinüriye sebep olur [2, 4]. Posterior nutcracker sendromu
(PNS) daha seyrek görülmektedir [5].

Tanı konulması birçok vakada zorlayıcı olabilir [1]. Hematüri şikâyetiyle başvuran her hastada hematürinin ortostatik yani ayakta kalmakla artıp artmadığı, meslek bilgilerini de içeren ayrıntılı öykü alınması çok önemlidir. Yeterli öykü alınmadığı durumda yanlış ön tanılar nedeniyle böbrek biyopsisi dahil olmak üzere gereksiz birçok tetkik ve girişimsel işlem yapılmış olabilir. Bu yazıda postural hematüri nedeniyle başvuran bir vakamızı özetledik.

Murat Yaşar Taş, Uzm. Dr. Pamukkale Üniversitesi Tıp Fakültesi, İç Hastalıkları Anabilim Dalı, Nefroloji Bilim Dalı, Denizli, Türkiye, e-posta: mrtysrts07@ yahoo.com (https://orcid.org/0000-0003-1459-1836) (Sorumlu Yazar)

Belda Dursun, Prof. Dr. Pamukkale Üniversitesi Tıp Fakültesi, İç Hastalıkları Anabilim Dalı, Nefroloji Bilim Dalı, Denizli, Türkiye, e-posta: belda. dursun@gmail.com (https://orcid.org/0000-0003-3235-0577)

Muhammet Arslan, Doç. Dr. Pamukkale Üniversitesi Tıp Fakültesi, Radyoloji Anabilim Dalı, Denizli, Türkiye, e-posta: dr.marslan@hotmail.com (https:/l orcid.org/0000-0001-5565-0770) 


\section{Olgu sunumu}

22 yaşında kadın hasta 4 yıldır devam eden makroskopik hematüri ve sol yan ağrısı şikâyetiyle başvurdu. Kuaförlük yaptığını, günde 12-16 saat ayakta iş yaptığını belirtti. Hematüri yakınmasının ayakta uzun süre kaldıktan sonra arttığını, sabah uyandığında idrar renginin normale döndüğünü ifade etti. Ateş ya da idrar yaparken yanma yakınması yoktu. Daha önce başvurduğu merkezde yapılan ve 38 glomerülü içeren böbrek biyopsisinin mikroskopi sonucu 'Tübülointerstisyel, hafif tübüler dejenerasyon dışında olağan sınırdadır. Vasküler yapılar olağandır. İmmünfloresans incelemede 7 glomerül izlenmiş olup, hafif C3 birikimi saptandı.' olarak raporlanmıştı. Yine aynı merkezde yapılan sistoskopi tetkiki normal olarak değerlendirilmiş ve hastaya herhangi bir tedavi önerilmemişti. Hematüri şikâyeti devam eden hasta, net tanı konulamadığı için endişeliydi. Postural hematüri nedeniyle NS ön tanısıyla yatırılarak tetkik edildi. Yatışı sırasında fizik muayenesinde patolojik bulgu yoktu. Laboratuvar tetkiklerinde böbrek fonksiyon testleri normal, eGFR CKD-EPI: $123 \mathrm{ml} / \mathrm{dk}$, TiT: Lökosit ++ , nitrit (-), protein + , idrar-Hb: +++, lökosit mikroskopisi: 23, eritrosit mikroskopisi: 4492, immünolojik tetkikleri negatif olarak sonuçlandı. İdrar sedimentinde yoğun izomorfik eritrositler izlendi, silendir görülmedi. Postural hematürisi olan hastanın intravenöz kontrastlı trifazik bilgisayarlı tomografisi 'Sol ana renal ven aorta ve SMA arasından geçerken normal kalibre izlendi. Solda aksesuar renal ven izlenmekte olup, retroaortik olarak vena kavaya dökülmektedir. Aorta posteriorunda belirgin ince kalibredir.' olarak raporlandı. Hasta PNS olarak değerlendirildi ve uzun süre ayakta kalmaması, mümkünse meslek değiştirmesinin faydalı olabileceği önerildi. Girişimsel radyoloji bölümünce stent uygulaması önerilmedi. Üroloji bölümünce hastada yoğun hematüri, proteinüri ve pelvik konjesyon sendromu olmaması nedeniyle cerrahi işlem önerilmedi.

\section{Tartışma}

Posterior nutcracker sendromu anatomik varyasyonla SRV'nin retroaortik yerleşimi sonucunda spinal kolonla aorta arasında kısmi sıkışmasından kaynaklanır ve renal venöz hipertansiyon, sol yan ağrısı, hematüri ve proteinüriye sebep olabilir [4]. Hematüriyle başvuran hastalarda öykü son derece önemlidir. İdrar renginde ayakta kalmakla hematürinin artması ve dinlenmekle bu durumun azalması postural hematüriyi akla getirmelidir. Meslek ve çalışma koşullarının ayrıntılı not edilmesi ve basit idrar analizinin dikkatli değerlendirilmesi, idrar sedimentinin incelenmesi elzemdir. Makroskopik hematüri yakınması olan hastalar için sorunun psikososyal boyutunun da dikkatle ele alınarak irdelenmesi gerekir. Hematürinin nedeninin açıklığa kavuşturulamaması hastada endişe oluşturabilir.

Sol renal venin retroaortik yerleşimi sıklığının \%1-3 arasında olduğu belirtilse de bunların çoğu asemptomatiktir ve PNS sıklığı net olarak bilinmemektedir [6]. Posterior nutcracker sendromu tanısı için henüz tanı kriterleri belirlenmemiştir [5]. Nutcracker sendromu, mikroskopik ya da makroskopik hematüri dışında sol yan ve karın ağrısı yapabilir [2]. Disparoni, dismenore, karın ağrısı, pelvik varisler ile karakterize pelvik konjesyon sendromuna sebep olabilir [2]. Hematürinin sebebi, artmış SRV basıncıyla renal forniks toplayıcı sistem ile varisler arasındaki ince duvarlı septumun rüptürüdür [2]. Ortostatik proteinüri eşlik edebilir [4]. Bizim vakamızda uzun süre ayakta kalmanın, yerçekimi etkisiyle konjesyona katkıda bulunması sonucunda makroskopik hematüri olması, hasta yatar pozisyona geçtiğinde konjesyonun azalmasıyla hematürinin kaybolması NS açısından tipiktir. Nutcracker sendromu genellikle kadınlarda hayatın üçüncü ve dördüncü dekatında tespit edilir. Diğer hematüri yapan sebeplerin dışlanması gerekir [1]. Tanısal yöntemler doppler ultrasonografi, bilgisayarlı tomografi, MR ve altın standart yöntem olarak SRV ile inferior vena cava arasındaki basınç farkının venografi ile ölçülmesidir $[5,6]$. Nutcracker sendromunun yönetimi ise tartışmalıdır ve spontan remisyon nedeniyle özellikle genç ve hafif hematürisi olan kişilerde izlem tercih edilir. 2 yıllık izlem sonunda persistan hematüri, ciddi yan ağrısı olanlarda stent uygulaması ya da cerrahi işlem düşünülebilir $[1,6]$.

Sonuç olarak, PNS henüz tanı kriterleri belirlenmemiş, nadir görülen, hematüri sebepleri araştırılırken dikkatli öykü alınarak hastaların gereksiz tekik ve invaziv girişimlerden 
korunması sağlanabilecek bir sendromdur. Hematüri yakınmasıyla başvuran hastalarda ön tanılar arasında düşünülmelidir. [1].

Çıkar ilişkisi: Yazarlar çıkar ilişkisi olmadığını beyan eder.

\section{Kaynaklar}

1. Ali El Dein B, Osman Y, Shehab El Din AB, El Diasty T, Mansour O, Ghoneim MA. Anterior and posterior nutcracker syndrome: a report on 11 cases. Transplant Proc 2003;35:851-853. https://doi.org/10.1016/s00411345(02)04026-5

2. Kurklinsky AK, Rooke TW. Nutcracker phenomenon and nutcracker syndrome. Mayo Clin Proc 2010;85:552559. https://doi.org/10.4065/mcp.2009.0586

3. Park JH, Lee GH, Lee SM, et al. Posterior nutcracker syndrome - a systematic review. Vasa 2018;47:23-29. https://doi.org/10.1024/0301-1526/a000670

4. Granata A, Clementi A, Floccari F, Di Lullo L, Basile A. An unusual case of posterior nutcracker syndrome. Clin Exp Nephrol 2014;18:670-671. https://doi.org/10.1007/ s10157-014-0932-y

5. Chen Y, Xing J, Liu F. Left renal vein transposition is effective for posterior nutcracker syndrome. Int J Clind Exp Med 2014;7:5925-5927.

6. Marone EM, Psacharopulo D, Kahlberg A, Coppi G, Chiesa R. Surgical treatment of posterior nutcracker syndrome. J Vasc Surg 2011;54:844-847. https://doi. org/10.1016/j.jvs.2011.01.038

Hasta onamı açıklaması: Hastadan yazılı olarak hasta onamı alınmıştır.

\section{Yazarların makaleye olan katkıları}

B.D. tarafından ortostatik hematüri ile başvuran hastada öntanıda Nutcracker Sendromu düşünülmüş ve gerçek tanıya gidilmesi sağlanmıştır. Olgu sunumunun planlanması ve yazılmasına katkıda bulunmuştur. M.Y.T. tarafından literatür taranmış, olgu vaka sunumu olarak yazıımıştır. Vakanın yönetimi sürecinde M.A. tarafından radyolojik görüntülemeleri değerlendirilmiş, uygun görülen radyolojik görüntüler yazımıza eklenmiştir. Ayrıca tüm yazarlar çalışmanın tamamını tartışmış ve son halini onaylamıştır. 